\title{
THE FIFTH AMENDMENT PLEA BEFORE CONGRESSIONAL COMMITTEES INVESTIGATING SUBVERSION: MOTIVES AND JUSTIFIABLE PRESUMPTIONS - A SURVEY OF 120 WITNESSES
}

\section{Daniel H. Pollitt†}

"I personally don't want to comment on the right of $a$. citizen to take the Fifth Amendment because I have no doubt that in some instances it is absolutely a basic safeguard of American liberty or it would not have been written as the Fifth Amendment to the Constitution; although I must say I probably share the common reaction if a man has to go to the Fifth Amendment, there must be something he doesn't want to tell."

-DWIGHT D. EISENHOWER ${ }^{1}$

The fifth amendment of the United States Constitution provides in part that "No person . . . shall be compelled in any criminal case to be a witness against himself." 2 The protection of this provision is available to witnesses before congressional committees when they are asked questions tending to connect them with criminal activity, ${ }^{3}$ and no adverse legal inference may be drawn from such a plea." But President Eisenhower undoubtedly echoed the popular view when he concluded that the amendment would not be invoked if the witness did not have "something he [did not] want to tell." One may suspect that this inference goes even further; that such a plea is in fact tantamount to an admission that the answer, if given, would be directly damaging to the witness. Why indeed should a person not a present member of the Communist Party refrain from denying such membership when all

$\dagger$ Associate Professor of Law, University of North Carolina.

1. N.Y. Times, March 28, 1957, p. 16, col. 2.

2. U.S. CoNsT. amend. V.

3. Emspak v. United States, 349 U.S. 190 (1955) ; cf. Counselman v. Hitchcock, 142 U.S. 547, 562 (1892).

4. Slochower v. Board of Educ., 350 U.S. 551, 557-58 (1956). 
can see and hear? One might logically expect a loyal American to deny with indignation a charge of espionage or sabotage.

The Supreme Court has recently condemned "the practice of imputing a sinister meaning to the exercise of a person's constitutional right under the Fifth Amendment." 5 Further, there is a substantial body of informed opinion which suggests that a witness might invoke the privilege for a variety of reasons logically unrelated to a conclusion of either guilt or innocence. ${ }^{6}$ To the extent that such selfserving declarations are credible, subsequent denials of guilt, in some cases under oath, by witnesses who have refused to answer tend to support this view. In addition, the fact that many witnesses who declined to answer questions relating to current acts of espionage have never been prosecuted at least permits the inference that the refusal to answer is unconnected with the existence of actually incriminating evidence.

Despite these arguments, the commion presumption of guilt persists. Collected data indicate that the informal social and economic sanctions which attend the use of the fifth amendment in the area of national security often produce acute hardship to both the witness and his family. ${ }^{7}$ Obviously in the case where the witness has something to hide, he may elect to use the privilege as the lesser evil. But if it can be established that at least in some cases the fifth amendment is not invoked as a cloak for guilt, one is forced to ask what possible motives could justify the individual in keeping his silence at such expense?

These and other questions have been posed and debated before. Nevertheless, there seems never to have been a previous attempt to pre-

5. Id. at 557. The Supreme Court declared further that, "The privilege against self-incrimination would be reduced to a hollow mockery if its exercise could be taken as equivalent either to a confession of guilt or a conclusive presumption of perjury. . . The privilege serves to protect the innocent who otherwise might be ensnared by ambiguous circumstances." Id. at 557-58.

6. See, e.g., Griswold, The Fifth Amendment Today (1955). See also CushMan, Civil Liberties IN THe UnIted States 143 (1956): "Many different motives have led witnesses to plead self-incrimination when questioned about their possible Communist affiliations. Some fear actual incrimination because of present Communist Party membership or fear various reprisals or stigmas if they admit past membership. Some resent legislative inquiries and their methods and use the plea to obstruct the inquiry, even though they have nothing damaging to conceal. Some resort to the plea in order to avoid giving evidence against their friends. . . . What stands out is the dearth of knowledge about the real reasons why many of these people have invoked the privilege against self-incrimination. A study of this whole complex situation is highly desirable."

7. One purpose of the survey reported in this Article was to find out what happens to witnesses who plead the amendment. See text at note 12 infra. Results indicate that refusal to answer congressional committee questions causes severe economic and social hardships. Seventy-five witnesses were employed by others at the time of their testimony. There is information concerning sixty-four of them. Fifty were fired, fourteen were retained on the job. Of the thirty-six witnesses who returned questionnaires, twenty-three reported threatening letters and/or phone calls. 
sent anything approaching a sizeable collection of data. ${ }^{8}$ It is true that a number of individual case histories are publicly available to shed some light on these queries. But one might legitimately expect that data pertaining to the few witnesses whose circumstances were such as to command an extensive amount of publicity would reflect atypical results. Thus, it was felt that some additional insight might be obtained from an "anonymous" investigation of a relatively large group of witnesses. This Article reports the results of such an investigation.

\section{The Method OF Inguiry}

The public documents of three congressional committees ${ }^{9}$ which have investigated un-American and subversive activities reveal that during the years 1953 and $1954^{10}$ some 368 witnesses relied upon the fifth amendment in refusing to answer questions relating to Communist Party membership, association with "Communist Front" organizations and/or illegal, seditious or subversive activities. As time would not permit a survey of all 368 witnesses, a sample of 120 was selected by a statistical method designed to insure impartiality. ${ }^{11}$

Essentially three lines of inquiry were pursued: (1) to what extent did background data concerning the witnesses tend to support any inferences of guilt or innocence; (2) what price was paid for the privilege of silence; and (3) what reasons were given for refusing to answer questions. This information was sought from three principal sources: (1) congressional committee transcripts and reports, (2) newspapers and other public documents, and (3) questionnaires sent to the witnesses.

Congressional committee transcripts, which are generally available to the public, disclose the number of witnesses who relied upon the fifth amendment, the questions the witnesses answered and refused to answer, the evidence adduced or presented by the committees in support (1955).

8. Cf. Williams, Problems of the Fifth Amendment, 24 FordHaM L. Rev. 19, 38

9. The Committees are the House Committee on Un-American Activities (then headed by Congressman Velde), the Permanent Subcommittee on Investigations of the Senate Committee on Government Operations (then headed by Senator McCarthy), and the Special Subcommittee on Internal Security of the Senate Judiciary Committee (then headed by Senator Jenner).

10. The years 1953 and 1954 were selected as the base period for this survey as that was the most recent two-year period for which the entire transcripts of the committee hearings had been made available to the public.

11. The 368 witnesses were listed and the 120 witnesses in this survey were picked from the total list of witnesses in accordance with an arbitrary Table of Random Numbers. The geographical distribution of the sample group corresponds with the geographical distribution of the total group. Both groups include witnesses from varied walks of life. The educational level of the witnesses in both groups runs a wide gamut. 
of the questions asked, and often the reasons advanced by the witnesses for so pleading. The transcripts sometimes disclose that witnesses have testified elsewhere on the same subject. ${ }^{12}$ In addition, the committees issue annual and other reports. These reports frequently discuss specific cases in detail, and disclose the testimony adverse to a particular witness as well as his activity and testimony elsewhere. ${ }^{13}$ Often the reports give the number and identity of witnesses discharged or suspended from their jobs as a result of the plea. ${ }^{14}$ Other principal sources disclosing the avowed reasons for pleading the fifth amendment and sometimes the information withheld are newspapers, court decisions, arbitration awards, legal briefs, and other public documents. ${ }^{15}$

A questionnaire divided into seven principal parts was sent to each of the 120 witnesses in the sample group. Five of these parts, substantially identical, related respectively to (1) membership in "Com-

12. Most frequently this testimony is found in applications for passports, jobs, or the right to represent a labor union under the Taft-Hartley Act. However, the testimony may have been given before a government agency or another committee. For example, a witness before the Committee headed by Congressman Velde denied membership in the Communist Party since March of 1951 but relied upon the amendment when asked about membership in February of 1951. Hearings Before the Committee on Un-American Activities, House of Representatives, Concerning Communist Methods of Infiltration (Education), 83d Cong., 1st Sess., pt. 2, at 252-53 (1953). The following year he gave this testimony before a different committee: "I attended the last meeting of the Communist Party group I ever attended on March 31, 1947." Hearings Before the Permanent Subcommittee on Investigation of the Committee on Government Operations, United States Senate, on Subversion and Espionnge in Defense Establishments and Industry, 83d Cong., 2d Sess., pt. 9, at 369 (1954).

The testimony may even be given before the same committee on another occasion. For example, a witness before the "Jenner Committee" in October of 1952 relied upon the amendment when asked about present Communist Party membership. In October of 1953 he testified before the same committee that he was not then a Communist and that he had not been a member of the Communist Party when he had appeared previously before the Committee. Hearings Before the Subcommittee To Investigate the Administration of the Internal Security Act and Other Internal Security Lazes of the Committee on the Judiciary, United States Senate, Concerning Activities of United States Citizens Employed by the United Nations, 83d Cong., 1st Sess., pt. 5, at 666 (1953).

13. See S. Rep. No. 230, 84th Cong., 1st Sess. 7 (1955).

14. See S. Rep. No. 231, 84th Cong., 1st Sess. 15 (1955).

15. See, e.g., In the matter of an Arbitration Between Bethlehem Steel Company and United Steelworkers, 24 Lab. Arb. 852 (1955). The arbitrators' report concerned the discharge of three employees for pleading the fifth amendment when questioned by a senate committee about espionage, sabotage, and present membership in the Communist Party. The report recited that all three employees denied under oath to the arbitrator that they had engaged in espionage or sabotage. Two of the employees denied membership in the Communist Party as of that time, or as of the date they testified before the Committee. The third employee denied present or past membership or affiliation with the Communist Party. The reason given by one of the employees for pleading the amendment before the Committee was that "he was fearful of a prosecution for perjury if he should give answers under oath different from those given by [an identified adverse witness]." The reason given by a second employee was that "he was formerly a member of the International Workers Organization and that he did not want to disclose the names of other IWO members." The report does not disclose the reason of the third employee. For similar cases see Labor Arbitration CusiuLATIVE DIGEST AND INDEX \$118.649. 
munist Front" organizations, ${ }^{16}$ (2) membership in the Communist Party prior to 1940 , (3) membership in the Communist Party between 1940 and 1950, (4) membership in the Communist Party since 1950 and (5) illegal activities such as espionage, sabotage, and conspiracy to overthrow the government by force and violence. ${ }^{17}$ Those witnesses who had been asked a question relating to one of the five items above were requested in the questionnaire to answer two general lines of inquiry: (1) had the witness testified concerning or otherwise answered the question elsewhere; if so to whom, under what circumstances, and the purport of his answer; and (2) had the witness disclosed his reasons or motives for pleading the fifth amendment; and if so to whom, under what circumstances, and the purport of this disclosure. The witness was not asked to disclose any information which he had not disclosed previously to others. The questionnaire had two additional parts relating respectively to the social and economic consequences of pleading the fifth amendment, and what the witness thought he would do if once again subpoenaed before the committee and asked the same questions. On the theory that those witnesses who had counsel would consult them prior to replying, their questionnaires were sent via their attorneys. ${ }^{18}$ Returns indicated that at least nineteen witnesses could not be located, and that six others would not return the questionnaire on the belief that the value of the survey did not warrant re-

16. Representative of questions asked witnesses by committees on this score are the following:

1. "Have you ever been a member of the American Youth for Democracy?"

2. 'Have you ever been a member of the Citizens' Committee To Free Earl Browder?"

3. "Do you recall in 1942 having an affiliation with the Joint Anti-Fascist Refugee Committee?"

See Hearings Before the Subcommittee To Investigate the Administration of the Internal Security Act and Other Internal Security Lazes of the Committee on the Judiciary of the Senate on Subversive Influence in the United Electrical, Radio, and Machine Workers of Americc, 83d Cong., 1st Sess., at 101-02 (1953).

17. Representative of questions asked witnesses by committees are the following:

1. "Did you at any Communist Party meetings hear the classified work at GE discussed?"

2. "Have you ever engaged in espionage?"

3. "You are at this time a functionary in the Communist underground espionage; that is correct, is it not?"

See Hearings Before the Permanent Subcommittee on Investigations of the Committee on Government Operations, United States Senate, on Subversion and Espionage in Defense Establishments and Industry, 83d Cong., 2d Sess., pts. 1, 2, at 11, 18, 92 (1954).

18. Six of the witnesses included in this survey were not represented by counsel at their committee testimony, and the questionnaires were sent directly to these six witnesses. A total of fifty-five lawyers represented the other 114 witnesses. Thirty of the fifty-five lawyers, representing an aggregate of seventy-six witnesses, acknowledged receipt of the questionnaire and promised to forward it to the witnesses they represented. Twenty-five of the lawyers, representing an aggregate of thirty-eight witnesses, failed to respond; and it is not known whether these lawyers forwarded the questionnaires to their clients. 
opening old wounds. Thirty-six witnesses returned questionnaires completed either in whole or in part. This constituted almost one-third of the witnesses in the sample group, and more than half of those known to have received the questionnaire.

A word of caution should perhaps be inserted prior to further discussion. The data consists almost entirely of facts culled from the printed word; it is therefore subject to the same doubts and infirmities as any other hearsay. I have no personal knowledge of any of the facts reported. In addition, many of the statements, especially in the area of witnesses' reasons for pleading the amendment, may be categorized as self-serving declarations. Finally, any conclusions which might be drawn from the data must of necessity be limited to the un-American activities arena. For obvious reasons fifth amendment pleas in the area of criminal activities might give rise to diametrically opposed conclusions.

\section{Presumptions To Be Drawn From the Plea}

Information deemed material in determining what inference might be drawn from the plea included: (1) testimony elsewhere by the witness, (2) evidence adduced from other witnesses, and (3) the reasons given by the witness for so pleading.

\section{Testimony Elsezhere by the Witness}

Any inference arising from the fifth amendment plea may be strengthened or weakened by the witness' testimony on the same subject elsewhere. If the witness pleads the amendment when asked about present Communist Party membership and then admits to the press outside the hearing room that he is a member, an adverse inference is obviously justified. On the other hand, if he subsequently tells his employer, his union, his friends that he is not a member, any adverse inference from the plea is weakened. It may be regarded as fully offset if the subsequent denial is under oath. The information gathered on this point is set forth in the chart on the facing page.

It is interesting although hardly surprising that witnesses seem less disposed to claim the amendment when the question is relatively innocuous, become more reticent when queried concerning Communist membership, and become somewhat talkative again when the question concerns the serious crime of espionage and sabotage. Many admit association with "Front" groups but all deny such activity as espionage. Nevertheless, assuming the witnesses either told the truth or would have given the same answers they gave in testimony beyond the chambers of the congressional committees, several significent facts emerge. Approximately half of those witnesses who relied upon the 


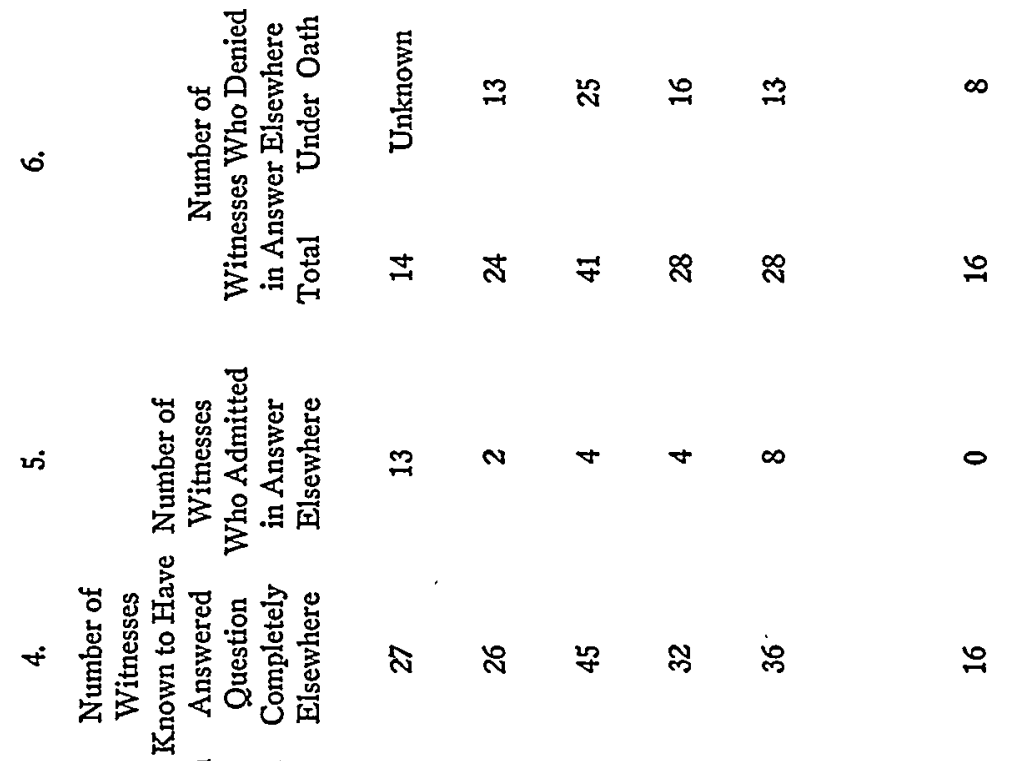
岁总实富

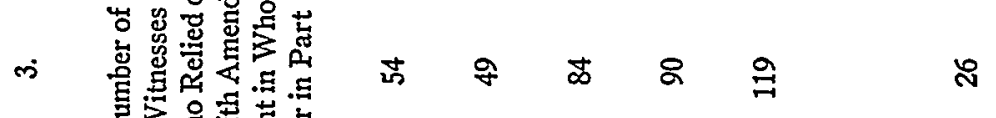

点

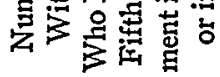

:

ลื

N



-

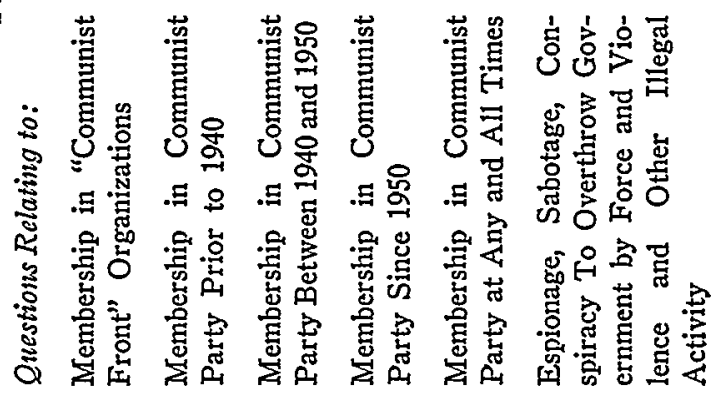


amendment when asked by the committees about the relatively innocuous matter of membership or participation in "Communist Front" organizations ${ }^{19}$ were not in fact members or would have denied participation in such organizations or activities. Approximately twothirds of the witnesses who relied upon the amendment when asked questions concerning criminal matters such as espionage and sabotage are known to have answered elsewhere, all of whom denied any guilt; half of these denials were made under oath. Of those asked specific questions concerning membership in the Communist Party, approximately half are known to have answered elsewhere, the great majority denying such membership. The percentages vary but little, be the question one relating to membership in the long distant past, in the 1940 's, or since 1950. Approximately one-fourth of the witnesses are known to have denied membership in the Communist Party at any and all times. ${ }^{20}$

\section{Evidence Adduced From Other Witnesses by the Committees}

Any adverse inference from a plea is strengthened by evidence adduced from other witnesses by the committees. For example, an inference that witness $A$ was a member of the Communist Party seems logical if he pleads the fifth amendment when asked about membership immediately following the testimony of witness $B$ that $B$ was a member of the Party up to a week ago and attended meetings at the home of witness A. Similarly, the inference seems logical when the committee reads to $A$ the testimony of prior witnesses that they had been members of the Party and had attended meetings with $A$. The adverse inference seems less logical when the committee, despite a practice of notifying witnesses of hostile testimony, adduces no such information.

The committees can and do adduce evidence adverse to a given witness by calling the witness to the stand immediately following adverse testimony, by adverting to prior testimony either from identified or unidentified sources, or by disclosing hitherto undisclosed adverse information.

The chart on the facing page contains information concerning those witnesses about whom the committees adduced adverse evidence in any of the four above described methods.

19. For representative questions, see note 16 supra.

20. Information on this point is incomplete. Some witnesses who returned questionnaires stated that in the mid or late 1940's they had formally denied present or past membership in the Communist Party but had refused as a matter of principle to make similar denials in the recent past. 

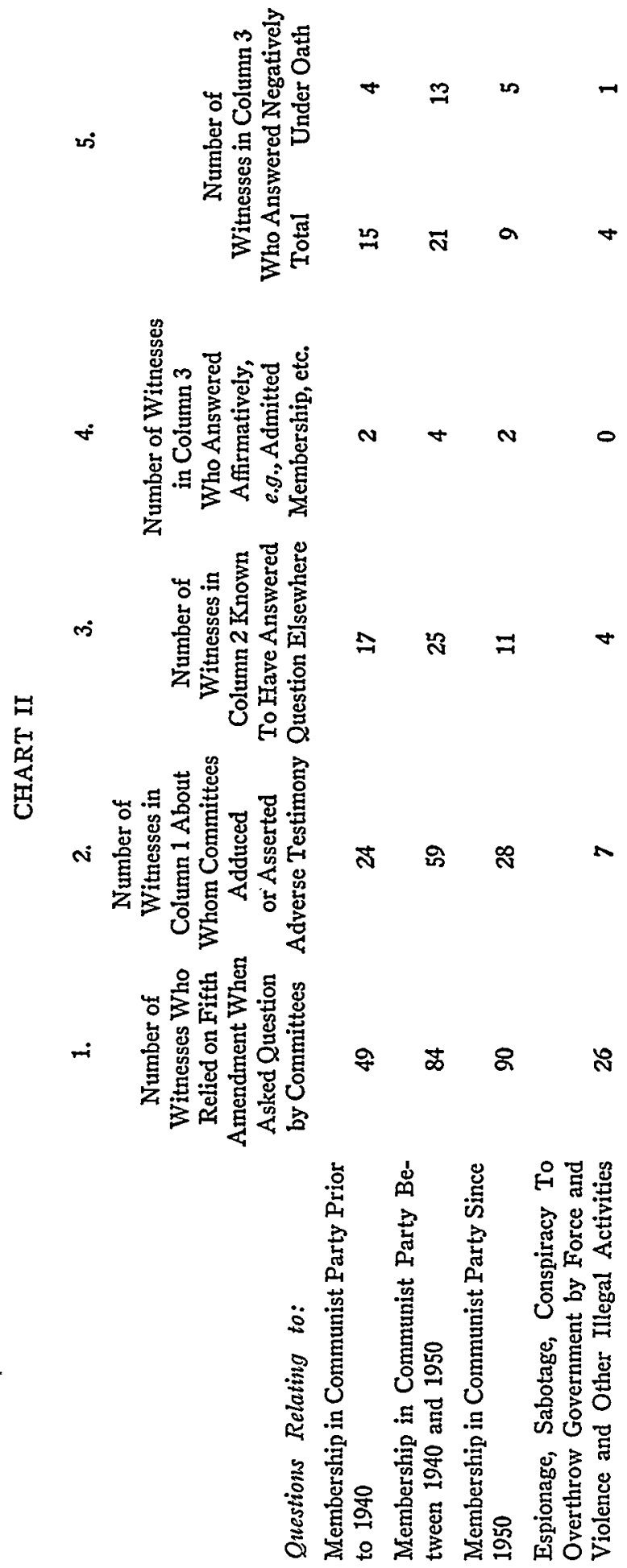
If the assumption be made that the committee staffs obtained all possible adverse information, and that the committees have adopted the practice of notifying witnesses of adverse testimony when such testimony is available, ${ }^{21}$ one conclusion to be drawn from the above statistics is that half the questions relating to membership in the Communist Party were asked without justification and consequently would have been answered in the negative had the witnesses not relied upon the fifth amendment. This fifty per cent figure approximates the percentage of witnesses who are known to have denied such membership outside the committee chambers when measured against the number of witnesses who refused to answer such committee questions. This committee failure to justify so many questions, despite a practice of discrediting fifth amendment witnesses whenever possible, weakens the adverse inference that might otherwise be drawn from the plea. Is the converse true? Does the presentation of adverse testimony in a given case strengthen the presumption of guilt?

The inference that a witness is or was a member of the Communist Party seems most logical when he is called to testify immediately following adverse testimony by a live witness. The witness pleading the fifth amendment is thus given opportunity to see and hear his accuser. ${ }^{22}$ The chart on the facing page contains information concerning those witnesses who were given opportunity to see and hear the adverse witness.

The above statistics show that a large proportion of those witnesses who see and hear the adverse informant deny elsewhere under oath the allegations of Communist Party membership. Subsequent to their congressional committee appearances, several of the adverse informants have either "recanted" or have been repudiated by the Government. ${ }^{23}$ None of the witnesses who relied upon the amendment, to the knowledge of this writer, have been indicted for perjury because of their subsequent denials of Communist Party membership. These facts indicate that the presumption of "guilt" is not necessarily strengthened by the congressional committee presentation of testimony adverse to the fifth amendment witness.

\section{Reasons Given by the Witnesses for Pleading the Fifth Amendment}

The protection of the fifth amendment is available to witnesses who fear that an answer to committee questions would tend to incriminate,

21. The committees adduced or asserted adverse information when asking approximately three-fourths of the questions relating to membership in the Communist Party between 1940 and 1950.

22. The witness does not "confront" his accuser in that, although he can see and listen, he cannot cross-examine.

23. See, e.g., Mesarosh v. United States, 352 U.S. 1 (1956). 

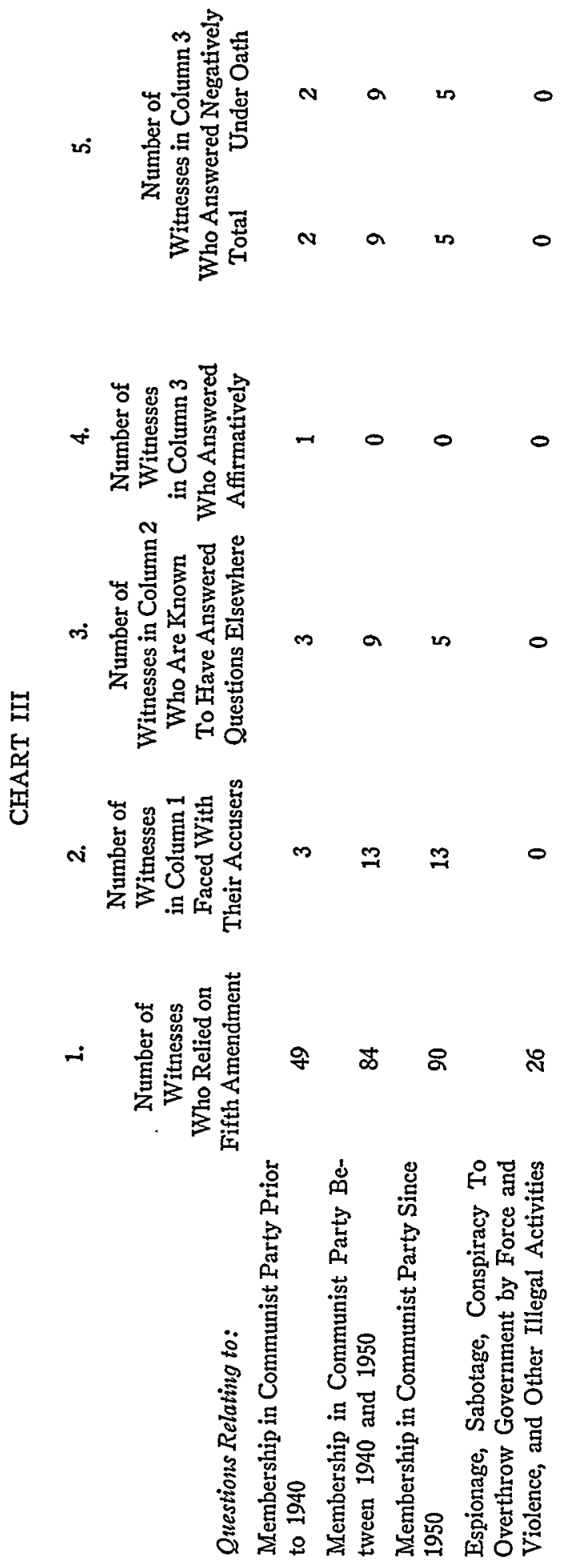
e.g., furnish a link in the chain of evidence helpful to the prosecution in a criminal case. ${ }^{24}$ To the extent that the refusal to answer is based on the known existence of actually incriminating evidence, the popularly accepted adverse presumption is probably justified. ${ }^{25}$ However, in any given case the chief operative motive behind an invocation of the privilege cannot be known except insofar as it may be inferred from surrounding circumstances. Of these surrounding circumstances, the witness' own explanation of his conduct is at the same time the most relevant and the least trustworthy evidence. Such statements may tend to be unreliable because of the understandable need of all witnesses to justify their refusal to cooperate on morally acceptable grounds. But where other evidence indicates the absence of actually incriminating matter, the reason asserted for pleading the amendment assumes a special persuasiveness in formulating the inference to be drawn from its use.

The various categories of reasons asserted by the witnesses for pleading the amendment are described below in order of priority assigned by the witnesses. They sometimes overlap and duplicate one another, but are used because given witnesses have often singled one out from others in replies to committees or the press.

\section{A Belief That the Question Infringes on the Witness' Freedom of Speech, Association or Conscience}

The witness who refuses to answer committee questions related to Communism solely on grounds of the first amendment faces almost certain contempt citation. ${ }^{26}$ The fifth amendment thus offers an attractive subterfuge for those witnesses who feel the committee questions invade their first amendment rights but fear to refuse

24. Over 150 years ago Chief Justice Marshall said that if a witness' statement that his answer would incriminate be untrue, "It is in conscience and in law as much a perjury as if he had declared any other untruth upon his oath." United States v. Burr, 25 Fed. Cas. 38, 40, No. 14,692e (4th Cir. 1807). However, some modern commentators believe that a non-communist is legally entitled to claim the privilege when asked about present Communist Party membership, for were it otherwise, the claim of the privilege would supply the link or clue that the amendment says need not be furnished. Kalven, Invoking the Fifth Amendment, 9 Bull. OF ATOMIC ScIENTISrs 181 (1953). The resolution of this problem is beyond the scope of this Article.

25. It by no means follows that the witness who claims the privilege when asked about Communist Party membership admits such membership, even when he claims the privilege to withhold clues that might be useful to the Government in event of a criminal prosecution. The witness who joined "Front" organizations but never the Party might fear that his honest denial of Party membership, followed by claim of the privilege when asked about "Front" membership, might "clue" the government to his "Front" membership. See Griswold, The FirTH AMrendMent TOdAy 19 (1955); Byse, Teachers and the Fifth Amendment, 102 U. PA. L. REv. 871, 876 (1954).

26. Pollitt, Pleading the Fifth Amendment Before a Congressional Committee: $A$ Study and Explanation, 32 NOTRE DAME LAw. 43, 49 (1956). 
cooperation for this reason. Whatever else might be said of this use of the fifth amendment, it serves to negate the inference that follows when the amendment is invoked to withhold facts potentially harmful to the witness in a criminal case.

\section{A Fear That Answering a Particular Question Would "Waive" the Right To Refuse To Answer Questions Concerning the Identity of Others}

The right to claim the fifth amendment presupposes a real danger of legal detriment to the witness. If the witness admits guilt, or furnishes clear proof of crime, he thereby "waives" the right to invoke the amendment as further admissions concerning details of the crime do not constitute a real danger of legal detriment. ${ }^{27}$ Congressional committees ${ }^{28}$ and the courts ${ }^{29}$ equate a witness' admission of Communist group participation with an admission of guilt that "waives" the right to invoke the amendment when asked related questions, including the identity of others in the group. The "waiver" doctrine requires the witness who wishes to shield others to withhold all information about himself. This use of the amendment does not necessarily mean that the witness engaged in Communist group participation, for he is told that his denial of such participation similarly precludes him from asserting the privilege when asked to name others he suspects of Communist Party membership. ${ }^{30}$

\section{A Fear of a Perjury Indictment if Questions Answered in the Negative}

The witness erroneously identified by prior witnesses as a Communist might fear a perjury indictment if he challenges this testimony, and invoke the amendment to protect himself from this possibility. ${ }^{31}$

27. McCarthy v. Arndstein, 262 U.S. 355 (1923).

28. See Hearings Before the Subconnmittee To Investigate the Adninistration of the Internal Security Act of the Senate Committee on the Judiciary, Subversive Influence in the Educational Process, 83d Cong., 1st Sess., pt. 12, at 1085 (1953).

29. Rogers v. United States, 340 U.S. 367 (1951); Singer v. United States, 244 F.2d 349 (D.C. Cir.), judgnent vacated on other grounds, 247 F.2d 535 (D.C. Cir. 1957).

30. "[T] he waiver doctrine is a lethal weapon, which they [the investigating committees] have not scrupled to employ ruthlessly. Senator McCarthy's favorite trick, for example, is to ask a witness whether or not he has ever engaged in Communist espionage. If the witness denied that he has, the Senator then takes the position that 'you have waived the Fifth Amendment insofar as the field of espionage is concerned' and puts a series of questions having to do with Communist association, threatening the witness with prosecution if he fails to answer. However, if the witness, perhaps to forestall the waiver doctrine, declines to state whether or not he is engaged in espionage, then the Senator promptly and loudly castigates him as a spy, as ripe for the electric chair as the Rosenbergs!" TAYLOR, GRAND INQUEST 201 (1955).

31. Paul Shipman Andrews, Dean Emeritus of the Syracuse University Law School, told the story of one witness who invoked the amendment despite an un- 
Although the courts have indicated that this use of the fifth amendment is not justifiable, ${ }^{32}$ it completely negates any adverse inference that the witness is attempting to hide criminal activity.

4. A Desire To Protect the Integrity of the Fifth Amendment or To Support the Position of Others Who Had Relied on It

An innocent witness might so resent the constant belittling of the amendment and those who use it that he pleads it to prove that its protection and use is not confined to the guilty. ${ }^{33}$ As will be shown hereinafter, approximately one-fourth of the witnesses who elsewhere denied Communist Party membership asserted this as a reason for their plea.

5. A Belief That Reliance on the Fifth Amendment Is the Only "Safe" Way To Refuse To Cooperate With the Committee

Neither the committees nor the courts have yet recognized any legal justification other than the fifth amendment for refusal to answer a pertinent committee question ${ }^{34}$ relating to Communism ${ }^{35}$ when the committee brings home to the witness the pertinency of the question ${ }^{36}$ and its desire for an answer. ${ }^{37}$ The fifth amendment provides the only safe method for withholding cooperation from a committee. This use of the amendment indicates that the witness dislikes the committee, its chairman, its techniques or its purposes, not necessarily that the witness has adverse information he wishes to conceal.

\section{A Belief That the Question Is Not Pertinent to the Committee's Business}

The authority of investigating committees is limited by their enabling resolutions. For example, Congress limited the investigating power of the Committee headed by Senator McCarthy to matters concerning "economy and efficiency" in government operations, and a

blemished and affirmative anti-Communist background because "he knew that if he stated under oath that he never had been a Communist he would thereby be contradicting the sworn testimony of the other professors, and that there might be . . a prosecution for perjury." N.Y. Herald Tribune, Oct. 26, 1953, p. 14, cols. 3-5.

32. See, e.g., United States v. Nesmith, 121 F. Supp. 758 (D.D.C. 1954) (dictum).

33. See Hearings Before the Subcommittee To Investigate the Administration of the Internal Security Laws of the Committee on the Judiciary, United States Senate, Concerning Interlocking Subversion in Governmental Departments, 83d Cong., 1st Sess., pt. 12, at 831 (1953).

34. Cf. Bowers v. United States, 202 F.2d 447 (D.C. Cir. 1953).

35. Cf. Rumely v. United States, 197 F.2d 166 (D.C. Cir. 1952), aff'd on other grounds, 345 U.S. 41 (1953).

36. Watkins v. United States, 354 U.S. 178 (1957).

37. Emspak v. United States, 349 U.S. 190 (1955). 
witness cannot be punished for refusal to answer a question unrelated thereto. $^{38}$ The witness who refuses to answer a question for the asserted reason that it is not "pertinent" does so at the risk that a reviewing court may disagree when it is too late for the witness to "purge" his contempt by answering..39 To avoid this risk, the witness may invoke the privilege of the fifth amendment rather than answer questions he believes improper and unauthorized. This use of the amendment does not indicate that the witness has damaging information he wishes to conceal.

7. A Fear That Answering a Particular Question Would "Waive" the Right To Plead the Amendment When Asked Other Questions About Own Activities

The "waiver" doctrine requires the witness to refuse to answer all questions in a given line of inquiry if he wishes to invoke the amendment to any one of these questions. ${ }^{40}$ Invoking the amendment for this reason indicates that answers to some but not all of the questions would be adverse to the witness.

8. A Fear That an Answer Would Cause Public Humiliation, Economic Hardship, or Social Ostracism to the Witness

This reason for the plea seems self-evident and justifies the conclusion that the answers withheld would be adverse to the witness.

\section{Other and Miscellaneous Reasons}

Witnesses gave reasons for their pleas apart from those discussed above. Among those given were:

a. The sixth amendment, which in the words of one witness, "grants me the right to be confronted with witnesses against me." 41

b. The ninth amendment, which provides that "the enumeration in the Constitution of certain rights shall not be construed to deny or disparage others retained by the people." Several witnesses stated that the "right to silence has been retained by the people." 42

38. United States v. Kamin, 135 F. Supp. 382 (D. Mass. 1955).

39. Sinclair v. United States, 279 U.S. 263, 299 (1929).

40. "[C]ommittees sometimes use a different technique. If a witness claims the privilege, a long series of related questions is put, to each of which the witness also pleads the privilege, to protect himself against waiver. A careful tally is kept of the number of times this occurs-a number limited only by the physical endurance of the participants-and at the end of the hearing it is solemnly reported that witness $X$ invoked the privilege against self-incrimination thirty-two or seventy-eight or umpteen times. In the newspapers this looks very insidious, but rarely do these numbers have any real significance whatsoever." TAXLOR, GRAND INQUEST 201 (1955).

41. Hearings Before the Committee on Un-American Activities, House of Representatives, Concerning Investigation of Communist Activities in the New York City Area, 83d Cong., 1st Sess., pt. 3, at 1375 (1953).

42. Cf. Patterson, The Forgotien Ninth Amendient 55 (1955). 
c. The tenth amendment, which reserves to the states or the people "the powers not delegated to the United States by the Constitution." Several witnesses in the field of education argued that for this reason they were beyond the reach of congressional action. $^{43}$

d. The due process clause of the fifth amendment. One witness stated: "I consider this entire investigation a' denial of due process of law, that under the guise of investigating legislation, this committee is actually holding a trial." 44

None of the above miscellaneous reasons for use of the amendment justify an inference that a witness pleading the amendment is hiding criminal activity.

The author knows the reasons given by eighty-seven of the 120 witnesses. Many gave more than one reason for refusal to answer during public testimony, and the questionnaires requested the witnesses to check nine stated reasons, if applicable, in order of priority. Although most witnesses complied, some checked three or four reasons without indicating priority. One explained that "it is difficult to assign priority since I feel they are all important." In tabulating the questionnaires, all reasons are counted when no priority was assigned. When witnesses assigned priority, only the first two are counted. For those witnesses who did not return questionnaires but gave multiple reasons elsewhere, only the first two are counted on the theory that the witness would first voice those most important to him. It was felt that any more restricted method of computation would eliminate reasons which might be important to a particular witness. The reasons given by the eighty-seven witnesses follow.

CHART IV

Possible Reason:

Number of Witnesses

Out of 87 Asserting

This Particular Reason

1. Belief That the Question Infringes on the Witness' Freedom of Speech, Association or Conscience

2. Fear That Answering a Particular Question Would "Waive" the Right To Refuse To Answer Questions Concerning the Identity of Others

43. Barenblatt v. United States, 240 F.2d 875 (D.C. Cir.), cert. granted and case remanded for further reconsideration in light of Watkins $v$. United States, 354 U.S. 930 (1957).

44. Cf. Kilbourn v. Thompson, 103 U.S. 168,190 (1880). 
3. Fear of Perjury Indictment if Questions Answered in Negative

4. Desire To Protect the Integrity of the Fifth Amendment or To Support the Position of Others Who Had Relied on It

5. Belief That Reliance on the Fifth Amendment Is the Only Safe Way To Refuse To Cooperate With the Committee

6. Belief That the Question Is Not Pertinent to the Committee's Business

7. Fear That Answering a Particular Question Would "Waive" the Right To Plead the Amendment When Asked Other Questions About Own Activities

8. Fear That an Answer Would Cause Public Humiliation, Economic Hardship, or Social Ostracism

9. Other and Miscellaneous Reasons

The chart on the next page correlates the above data with the different types of questions which the witness had refused to answer, i.e., membership in "Communist Front" organizations, present membership in the Communist Party, acts of espionage, etc. The chart also separates the reasons given by those witnesses who returned questionnaires from those who did not. From the questionnaire the author learned the reasons given by the witness to friends and associates. If the witness failed to return a questionnaire, the only source of his reasons are those he asserted in public, to the committee or to the press. The author believes that the reasons given by a witness to his friends are less "self-serving" than the reasons he gives to the committee. For example, many witnesses who returned questionnaires said they relied on the amendment for fear of a perjury indictment, whereas few witnesses told this to the committees.

A category of witnesses whose reasons deserve special attention relied upon the amendment before congressional committees but elsewhere denied, in some cases under oath, all allegations of Communist Party membership. Assuming the witnesses would have answered the committee questions the same way, their refusal to answer must rest on reasons other than fear of incrimination. The reasons asserted by these witnesses thus serve as a measuring rod to test the validity of the reasons asserted by other witnesses. Twenty-eight of the witnesses in this survey are known to have testified subsequent to their congres- 


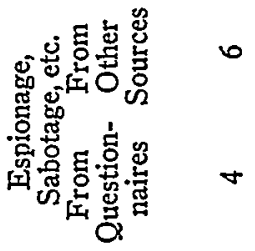

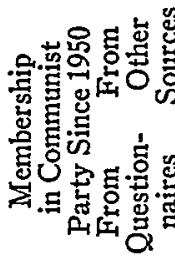

กิ

a $\times 1+1$

$1 \quad 11$

$\because \stackrel{\circ}{\because} \stackrel{2}{\rightarrow} 9 \cong$

으 $\rightarrow 1$

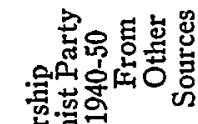

A

N $1+$

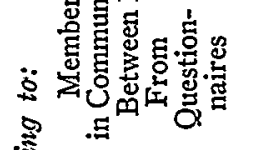

구 $9 \quad \rightarrow a$

$\infty \quad \exists N$

范葶

跑

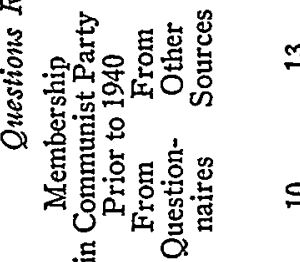

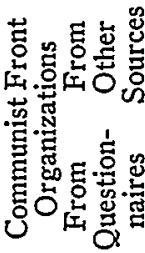

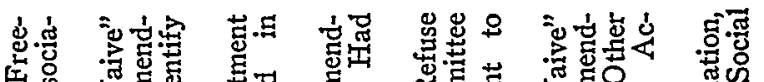

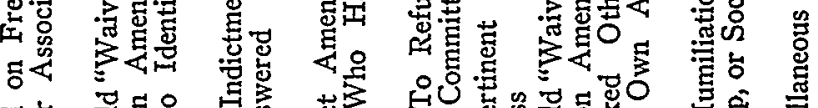

总

题

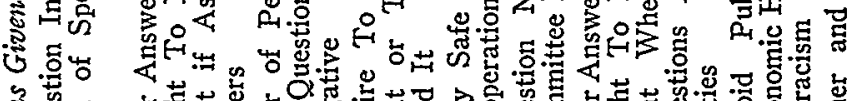

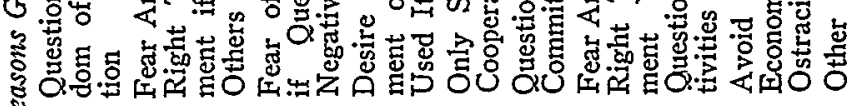

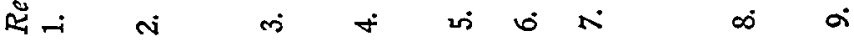


sional committee hearings and denied all allegations of Communist Party membership, thirteen of them under oath. Twenty-two of these witnesses have made known their reasons for pleading the amendment to committee questions, and fourteen of them returned questionnaires. Their reasons follow.

\section{CHART VI}

Reasons Given:

1. Question Infringed on Freedom of Speech, Association or Conscience

2. Fear Answer Would "Waive" Right To Rely on Amendment if Asked To Identify Others

3. Fear of Perjury Indictment if Question Answered in Negative

4. Desire To Protect Amendment or Others Who Had Relied on It

5. Only Safe Way To Refuse Cooperation With Committee

6. Question Not Pertinent to Committee Business

7. Fear Answer Would "Waive" Right To Rely on Amendment if Asked Other Questions About Own Activities

8. Avoid Public Humiliation, Economic Hardship, or Social Ostracism

9. Other and Miscellaneous

$\begin{array}{cc}\text { By Those } & \text { By Those } \\ \text { Who Returned } & \text { Who Did } \\ \text { Question- } & \text { Not Return } \\ \text { naires (14 } & \text { Questionnaires } \\ \text { witnesses) } & \text { (8witnesses) }\end{array}$

5

7

11

0

3

2

6

0

4

0

2

0

0

0

0

0

1

A final category of witnesses which deserves mention consists of those who relied upon the amendment before the committees but elsewhere admitted Communist Party membership, indicating that these witnesses were not motivated in their refusal to answer committee questions by fear of providing clues which might be useful to the Government in a criminal prosecution. Eight of the witnesses in this 
survey are in this category, seven of whom have made their reasons known, six of whom returned questionnaires. Their reasons follow.

CHART VII

Reasons Given:

1. Question infringed on Freedom of Speech, Association or Conscience

2. Fear Answer Would "Waive" Right To Rely on Amendment if Asked To Identify Others

3. Fear of Perjury Indictment if Question Answered in Negative

4. Desire To Protect Amendment or Others Who Had Relied on It

Number of Witnesses

Out of 7 Who

Considered This

Reason Important

5. Only Safe Way To Refuse Cooperation With Committee

6. Question Not Pertinent to Committee Business

7. Fear Answer Would "Waive" Right To Rely on Amendment if Asked Other Questions About Own Activities

8. Avoid Public Humiliation, Economic Hardship, or Social Ostracism

9. Other and Miscellaneous

Taken at face value, the above statistics demonstrate that most witnesses who rely upon the amendment do so for reasons apart from fear of incrimination, thereby emasculating the premise which most strongly supports the conclusion that the withheld answer is adverse to the witness. ${ }^{45}$ The argument will be made that, since the data they express consists of self-serving declarations, the figures are fictitious and the conclusions unsupported. However, several factors indicate that this is not the case:

First, a large percentage of witnesses are known to have elsewhere answered the committee questions, ${ }^{46}$ indicating that their plea of the

45. Only two of the thirty-six witnesses who returned questionnaires stated that fear of incrimination motivated their pleas of the amendment, and these two witnesses further stated that this reason for their plea was secondary.

46. See Chart 1 at p. 1123 supra. 
amendment was motivated by reasons other than fear of disclosing information helpful to the Government in event of criminal prosecution.

Second, the reasons asserted by those who are known to have answered the questions elsewhere (presumably the true reasons) correlate with and thereby support the validity of the reasons asserted by those witnesses about whom this information is lacking. ${ }^{47}$

Third, the questionnaire asked the witnesses if, subpoenaed again and offered immunity from criminal prosecution, they would answer the committee questions. Thirty-three of the witnesses (approximately one-fourth of all the witnesses in this survey) answered; all said "no." This response negates the view that the amendment was invoked for fear of incrimination, as the. "immunity offer" removes this fear.

In conclusion, it may be said that the facts developed here indicate that the term "Fifth Amendment Communist" has little basis in fact; for the committees often lack justification for asking the questions to which the amendment is invoked, and the witness freely answers the questions elsewhere with denials of the charge and with reasons for his committee silence which either negate or neutralize the theoretical basis for an adverse presumption.

47. Compare Charts VI (p. 1135 supra) and VII (p. 1136 supra) with Charts IV (p. 1132 supra) and V (p. 1134 supra). 